\title{
Body mass index of Hypertensive and non Hypertensive Residents in a Semi-urban area of Bayelsa, Nigeria.
}

\author{
${ }^{1}$ Allagoa Erefagha Leonardo Prince, ${ }^{2}$ Mukoro Duke George, \\ ${ }^{3}$ Allagoa-Gbobo Daunakige Dorcas \\ B.sc,MBBS,M.SC. B.sc,MBBS,HSE,ATLScert,DTM\&H $\mathrm{H}_{\text {Liverpoo. }}$ B.sc \\ 1. Department of Surgery, NDUTH, Okolobiri, Yenagoa, Bayelsa State. NIGERIA \\ 2.Department of Accident and Emergency, Niger-Delta University Teaching Hospital, Okolobiri, Yenagoa, \\ Bayelsa. NIGERIA \\ 3. Department of Anatomy, College of Medical Sciences,University of Benin.Benin city,Edo state. \\ Correspondence: Dr Mukoro duke George, mukoroduke@gmail.com
}

Abstract: Introduction: Obesity and hypertension are non-communicable diseases of public interests. There is a strong interplay among the risk factors implicated in both Obesity and Hypertension. The alarming rate at which these diseases increase worldwide, calls for serious concern amongst the scientific community. The continuous presence of the risk factors associated with these diseases, eventually leads to dreadful complications that may ultimately results in morbidities affecting the quality of life.

Objective: The research was to investigate the distribution of the various classes of body mass index(BMI) amongst hypertensive and non-hypertensive groups, and determined the crude rate of overweight and obesity as well as it's relationship to hypertension as a risk factor amongst residents in (Yenagoa) a suburban area, However, literatures of such investigations in the studied population was scarce.

Method: A total of two hundred and seventy four subjects between the ages of 18-85 years were sampled. Out of which,162 were non-hypertensive while 112 were hypertensive, both groups are residents in Yenagoa which is the capital of Bayelsa state, Nigeria. Their weight, height were measured and Body mass index was (BMI) determined.

Ethical clearance and participant's informed consent were obtained.

Results where collated and analyzed using SPSS version 17.

Results: $57.2 \%$ of the studied population composed of indigent and non indigent (migrants) were above the normal weight as defined by BMI, while $25.5 \%$ were obesed.A quarter of the obese population were above 60 years of age. There was a steady rise in the crude rate of obese persons with increase in age. At $p$ value of $<0.05$, there was significant association of obesity with the hypertensive group. Results also revealed that indigenes of Bayelsa(Izon) does not influence the crude rate of obesity in the studied group.

Conclusion: Obesity increases with age and is closely associated with hypertension while Sedentary lifestyle accentuates with age, therefore, increased physical activity, regular blood pressure check-up and healthy food options with reduced saturated fat intake can reduced the incidence of obesity and hypertension as well as their complications. Public efforts to reduce obesity and hypertension should be increased in urban areas in developing countries.

Keywords: Hypertension, obesity, body mass index, overweight

\section{Introduction;}

There are steady reports of worldwide increase in obesity ${ }^{1,2}$. The increasing trend of hypertension and obesity in metropolitan cities is alarming. The increase in adiposity or hypertension in developing setting is often attributed to socioeconomic ${ }^{3,4}$ status, reduced physical activities, ${ }^{3,4}$ westernization of life style and urbanization $^{5,6,7}$.There are confirming reports from Southern region Nigeria as well ${ }^{8-11}$. Africans seem to be more susceptible to elevated blood pressure and excessive adiposity than other regions of the world and are the most severely affected ${ }^{7,12}$. Another report ${ }^{13}$ showed that hypertension associated with ageing is more in black Africans adopting western lifestyle and worsened in Americans of African origin than those of European origin. Genetic and environmental factors have been implicated in hypertension ${ }^{14}$. Most hypertensive clients are classified as idiopathic ${ }^{15}$. High blood pressure impacts highly on the economy and on the quality of life of individuals. A rapid increase in adopting Western culture have characterized Nigerians living in urban areas ${ }^{11}$. Studies concerning issues on Obesity and Hypertension on Bayelsa metropolitans are scarce.This study examines the distribution of Hypertension among various body mass index groups among Niger-Delta residents in Nigeria. 


\section{Materials and Method:}

The study was a prospective study conducted in Bayelsa state, Nigeria. The population sampled were drawn from Niger-delta University community in Amassoma, and hypertensive out-patients in Federal medical centre in Yenagoa. The state is the home town to the indigenous Izon tribe, with migration of other tribes such as Igbos and Urhobos. A total of two hundred and seventy four subjects between the ages of 18-85 years were assessed; 162 were non hypertensive while 112 were hypertensive, both groups are residents of Yenagoa which is the capital of Bayelsa state. The instrument used for the study included clinical weighing scale, standiometer, measuring tape, and recording materials. Their weights, heights were measured and Body mass index was calculated as. BMI=weight $/$ height ${ }^{2}\left[\mathrm{Kg} / \mathrm{m}^{2}\right]$.

Those who are less than 18 or greater than 86 years old, hypertensive persons on drugs, and diabetic with or without hypertension, weight lifters were all excluded from the study, because these factors would affect the BMI of the populace.

\section{Ethical Issues:}

Ethical approval to conduct the study was obtained from the department of medicine, Niger-Delta University Teaching Hospital. Verbal informed consent was obtained from each participant before inclusion into the study.

\section{Data Analysis}

The data was analyzed using version 17.0 of the statistical package for social sciences(SPSS).The results were analyzed and the age distribution of various groups of BMI categorized. The relationship between hypertension and obesity was determined. Chi-square and T-test was calculated using the SPSS. Pearson's correlation co-efficient was determined to test the strength of relationship between age and prevalence of obesity.

\section{Results:}

Confidence interval was set at 95\%, and interpretation significance was made at probability $(\mathrm{p}<0.05)$.

A total of 274 participants were studied. Sex distribution was 153 males and 121 females .Age and tribe distribution of studied population are shown below.

Table 1: Sex, Age and tribe Distribution of the sampled population

\begin{tabular}{lll}
\multicolumn{2}{c}{ Table 1: Sex, Age and tribe Distribution of the sampled population } \\
\hline Parameters (sex) & Frequency & Percentage (\%) \\
\hline Male & 153 & 55.83 \\
female & 121 & 44.17 \\
Age distribution & Frequency & Percentage \\
\hline$<20$ & 7 & 2.60 \\
$20-29$ & 99 & 36.10 \\
$30-39$ & 31 & 11.30 \\
$40-49$ & 34 & 12.40 \\
$50-59$ & 41 & 15.00 \\
60 and above & 62 & 22.60 \\
Total & 274 & 100 \\
Izon TRIBE & 202 & 73.72 \\
NON-Izon & 72 & 22.28 \\
\hline Total & 274 & 100 \\
\hline
\end{tabular}

The body mass index were distributed into the following categories : Underweight ( $<18.5$ ), normal ( 18.5- 25), overweight ( 25-30), obese ( $>30)$. Expressed unit $=\mathrm{Kg} / \mathrm{m}^{2}$

Table 2: Body mass index distribution among different age groups

\begin{tabular}{|c|c|c|c|c|c|}
\hline AGE & Underweight & Normal weight & Overweight & Obese & Total \\
\hline $\begin{array}{ll}<20 & \text { Frequency } \\
& \text { Percent }\end{array}$ & $0.00 \%$ & $\begin{array}{l}6 \\
2.20 \%\end{array}$ & $\begin{array}{l}1 \\
0.40 \%\end{array}$ & $\begin{array}{l}0 \\
0.00 \%\end{array}$ & $\begin{array}{l}7 \\
2.60\end{array}$ \\
\hline $\begin{array}{c}\text { 20-29 Frequency } \\
\text { Percent } \\
\end{array}$ & $\begin{array}{l}7 \\
2.60 \% \\
\end{array}$ & $\begin{array}{l}54 \\
19.70 \% \\
\end{array}$ & $\begin{array}{l}29 \\
10.60 \%\end{array}$ & $\begin{array}{l}9 \\
3.30 \% \\
\end{array}$ & $\begin{array}{l}99 \\
36.10 \%\end{array}$ \\
\hline $\begin{array}{l}\text { 30-39 } \begin{array}{l}\text { Frequency } \\
\text { Percent }\end{array}\end{array}$ & $\begin{array}{l}3 \\
1.10 \%\end{array}$ & $\begin{array}{l}11 \\
4.00 \%\end{array}$ & $\begin{array}{l}9 \\
3.30 \%\end{array}$ & $\begin{array}{l}8 \\
2.90 \%\end{array}$ & $\begin{array}{l}31 \\
11.30 \%\end{array}$ \\
\hline $\begin{array}{cc}40-49 & \text { Frequency } \\
& \text { Percent }\end{array}$ & $\begin{array}{l}0 \\
0.00 \% \\
\end{array}$ & $\begin{array}{l}11 \\
4.00 \% \\
\end{array}$ & $\begin{array}{l}10 \\
3.60 \% \\
\end{array}$ & $\begin{array}{l}13 \\
4.70 \% \\
\end{array}$ & $\begin{array}{l}34 \\
12.40 \%\end{array}$ \\
\hline $\begin{array}{c}\text { 50-59 Frequency } \\
\text { Percent }\end{array}$ & $\begin{array}{l}0 \\
0.00 \% \\
\end{array}$ & $\begin{array}{l}10 \\
3.60 \% \\
\end{array}$ & $\begin{array}{l}15 \\
5.50 \%\end{array}$ & $\begin{array}{l}16 \\
5.80 \%\end{array}$ & $\begin{array}{l}41 \\
22.60 \%\end{array}$ \\
\hline $\begin{array}{c}\text { 60+ } \begin{array}{l}\text { Frequency } \\
\text { Percent }\end{array}\end{array}$ & $\begin{array}{l}2 \\
0.70 \%\end{array}$ & $\begin{array}{l}9 \\
3.30 \%\end{array}$ & $\begin{array}{l}27 \\
9.90 \%\end{array}$ & $\begin{array}{l}24 \\
8.80 \%\end{array}$ & $\begin{array}{l}274 \\
100.00 \%\end{array}$ \\
\hline $\begin{array}{cl}\text { Total } & \text { Frequency } \\
& \text { Percent }\end{array}$ & $\begin{array}{l}12 \\
4.40 \%\end{array}$ & $\begin{array}{l}101 \\
36.90 \%\end{array}$ & $\begin{array}{l}91 \\
33.20 \%\end{array}$ & $\begin{array}{l}70 \\
25.50 \%\end{array}$ & $\begin{array}{l}274 \\
100.00 \%\end{array}$ \\
\hline
\end{tabular}


From table 2 ,Those above normal weight were observed in about $57.2 \%$ of the studied population, while $25.5 \%$ were obese, a quarter of the obese people were above 60 years of age. There was a steady rise in the crude rate of obese persons as age increases.

Table 3: The BMI of hypertensive and Non-hypertensive persons

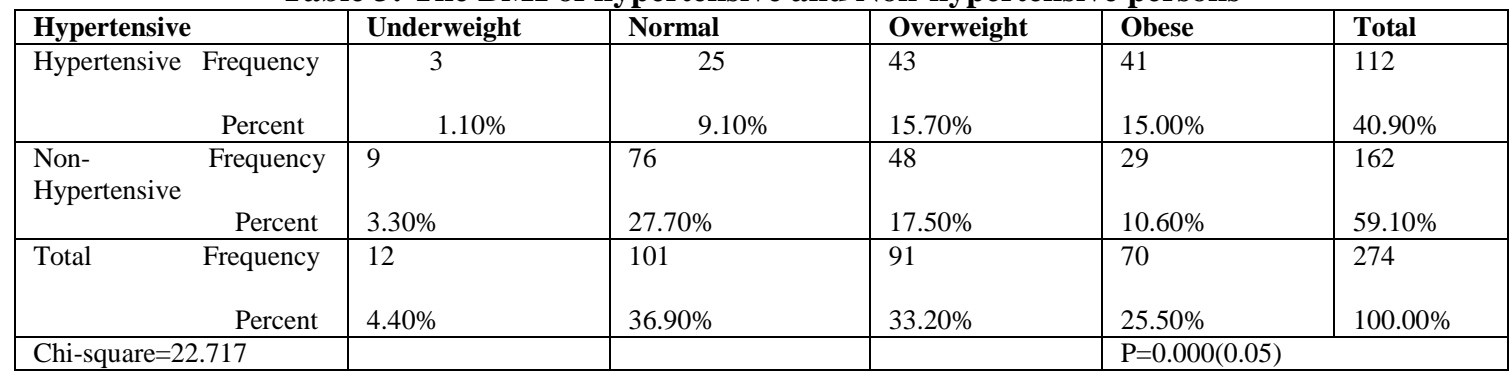

The third table shows distribution of the various body mass index classes among hypertensive and non Hypertensive groups. Results revealed that greater than half of of the sampled population were overweight or obesed. More'so, there was a statistic significant association of hypertension with obesity.

Table4: BMI distribution among Ijaws(indigenes) and Non Ijaws(Non-Ijaws)

\begin{tabular}{|c|c|c|c|c|c|}
\hline Hypertensive & Underweight & Normal & Overweight & Obese & Total \\
\hline \multirow[t]{2}{*}{ IZon } & 10 & 84 & 59 & 49 & 202 \\
\hline & $3.60 \%$ & $30.70 \%$ & $21.50 \%$ & $17.90 \%$ & $73.70 \%$ \\
\hline Frequency & 2 & 18 & 32 & 20 & 72 \\
\hline $\begin{array}{l}\text { Non- } \\
\text { Izon }\end{array}$ & $0.70 \%$ & $6.60 \%$ & $11.70 \%$ & $7.30 \%$ & $26.30 \%$ \\
\hline \multirow{3}{*}{$\begin{array}{lr}\text { Percent } \\
\text { Chi-square }=7.078\end{array}$} & 12 & 102 & 91 & 69 & 274 \\
\hline & $4.40 \%$ & $37.20 \%$ & $33.20 \%$ & $25.20 \%$ & $100.00 \%$ \\
\hline & & & & $\mathrm{p}=0.069$ & \\
\hline
\end{tabular}

The fourth table showed that, the distribution of body mass index was not affected by tribe in the study. Therefore determinates for hypertension and obesity was the same for both indigenous and non-indigenous group.

\section{Discussion:}

Hypertension has contributed significantly to the burden of cardiovascular diseases. The rate of increase of this non-communicable disease has placed it among the public health issues of today ${ }^{16}$. Several risk factors have been associated with this disease and these risks factors are increasing in their frequencies among population in developing countries ${ }^{8-11 ., 15}$. Currently, the crude rate of hypertension in semi-urban community of Southern -Ijaw area was reported to be $15.0 \%{ }^{17}$.

Obesity is one of the risk factors of Hypertension and re-affirmed by the study. The increasing prevalence of obesity and its complications have been attributed to the change in nutritional habits among metropolitans in most developing countries. Today, many fast food restaurant are been established in most developing cities. Most of their bakeries and cooked foods are made with a high content of saturated fats and cholesterol, therefore, as financial status improve, people do not opt for healthy food options. The contributions of sedentary lifestyle to obesity cannot be undermined as revealed by Joffa et $\boldsymbol{l}^{18}$, as well as the preference of white collar jobs by majority of the population. The significant role of obesity in contributing to hypertension cannot be over-emphasized. Greater than 55 percent of the studied population are Overweight or obese, and they are mostly distributed among the ages of 20-29 years of age as well as those greater than 60 years of age. There is a gradual increase in rate of overweight and obesity from 30 years of age ${ }^{(\text {Table2) }}$.Pointing out the fact that as age progress, physical activities reduces and obesity set-in.

Statistically, significant association of hypertension with obesity was observed when comparing hypertensive groups to non-hypertensive groups ${ }^{(\text {Table4) }}$.A Current study corroborates with these findings ${ }^{19}$. A study ${ }^{18}$ from same region reported that men are more disposed to obesity than the female; result revealed that males were overweight while females were within normal weight spectrum.

The values of table 4 shows that Izon indigenes are not the determinants of over -weight or obesity observed in this study, but that the risk factors that may be implicated affects the studied population evenly irrespective of the tribe of the population.

Body mass index is a very important factor that must be monitored by individuals and nutritionist in order to control hypertension. Other parameters that can be used include skin-fold, bioelectric impedance, near 
infrared interactance, and body circumference. Any increase in these anthropometric parameters above normal can be significantly controlled through healthy nutrition, reduced saturated fat intake, reduced salt intake and reduced food spices containing sodium glutamate, and exercise thereby helping to reduce blood pressure ${ }^{20}$. Regular check-up of blood pressure is an essential modality in preventing complications such as stroke ${ }^{19}$, renal failure, loss of eye sight and heart failure. Overweight and obesity are associated with increased risk for many types of cancer, including cancer of the breast, colon, endometrium, esophagus, kidney, pancreas, gall bladder, thyroid gland, ovary, cervix, and prostate, as well as multiple myeloma and Hodgkin's lymphoma. ${ }^{21}$

\section{Conclusion:}

Public health interventions such as mass enlightenment programmes, on exercise, healthy nutrition and provision of clinical services would play a long term role to enforce healthy food habits among the populace.

\section{Reference :}

[1]. Flegal KM, Carroll MD, Kuczermarski RJ, Johnson CL. Overweight in the US. Int J Obes Relat Metab Disord. 1988;22:39-4.

[2]. Delpeuch F, Maire B. Obesity and developing countries of the south. Med Trop. 1997;57:380-388.

[3]. Sobal J, Stunkard AJ. Socioeconomic status and obesity: a review of the literature. Psycho Bull. 1989;105:260-275.

[4]. Gortmaker SL, Must A, Perrin JM, Sobal AM, Dietz WH. Social and economic consequences of overweight in adolescence and young adulthood. N Engl J Med.

[5]. Ramadan J, Barac-Nieto M. Reported frequency of physical activity, fitness, and fatness in Kuwait. Am J Hum Bio. 2003;15(4):514-521.

[6]. Al Muhailan ARS, Ramadan J, Gjorgov AN, Moussa M. Assessment of selected coronary risk factors in adult Kuwaiti males. Med Princip Pract. 1990;2:199-203.

[7]. Cooper R, Rotimi C. Hypertension in blacks. Am J Hypertens. 1997;10:804-812.

[8]. Cooper R, Rotimi C, Ataman S, et al. The prevalence of hypertension in seven populations of West African origin. Am J Publ Health. 1997;87:160-168.

[9]. Gwatkin D, Guillot M, Heuveline P. The burden of disease among the global poor. Lancet. 1999;354:586-589.

[10]. Cappuccio FP, Cook DG, Atkinson RW, Strazzullo P. Prevalence, detection, and management of cardiovascular risk factors in different ethnic groups in south London. Heart. 1997; 78:555-563.

[11]. Erhun WO, Olayiwola G, Agbani EO, Omotoso NS. Prevalence of Hypertension in a University Community in South West Nigeria. Afr J Biomed Res. 2005;8:15-19.

[12]. Forrester T, Cooper RS, Wetherall D. Emergence of Western diseases in the tropical world: the experience with chronic cardiovascular diseases. Br Med Bull. 1998;52:463-473.

[13]. Shaper AG, Whincup PH. Hypertension in populations of African origin. Am J Publ Health. 1997;87:155-156.

[14]. Edwards RU, Nigel M, Ferdinand W, et al. Hypertension prevalence and care in an urban and rural area of Tanzania. J Hypert. 2000;18:145-152.

[15]. Jervase Ekezie, Emeka G Anyanwu, Barnabas Danborno, and Ugochukwu Anthony: Impact of urbanization on obesity, anthropometric profile and blood pressure in the Igbos of Nigeria. N Am J Med Sci. 2011 May; 3(5): 242-246. PMCID: PMC333774

[16]. Mary T. Bassett, Sarah Perl,Obesity: The Public Health Challenge of Our Time Am J Public Health. 2004 September; $94(9)$ : 1477. PMCID: PMC1448475

[17]. Ismail A Suleiman, Ebubechukwu O Amogu, Kehinde A Ganiyu: Prevalence and control of hypertension in a Niger Delta semi urban community, Nigeria. Pharmacy practice Vol 11, No 1 (2013)

[18]. Joffa Paul Kwaku Price, Nwafor Arthur and Adienbo Ologhaguo Macstephen: Correlation between Body Mass Index and Peak Expiratory Flow Rate of an Indigenous Nigerian Population in the Niger Delta Region.Res. J. Recent Sci. Vol. 2(2), 28-32, February (2013)

[19]. A Oni, A Eweka, P Otuaga, V Prefa. The incidence and pattern of stroke in bayelsa state, Nigeria. The Internet Journal of Third World Medicine. 2008 Volume 8 Number 1.

[20]. Donnan GA, Fisher M, Macleod M, Davis SM. "Stroke". Lancet May 2008, 371 (9624): 1612-23.

[21]. Kushi LH, Byers T, Doyle C, Bandera EV, McCullough M, Gansler T, et al. American Cancer Society guidelines on nutrition and physical activity for cancer prevention: reducing the risk of cancer with healthy food choices and physical activity. CA: A Cancer Journal for Clinicians 2006;56:254-281. 